\title{
Susan Hunter: AIDS in Asia. A Continent in Peril.
}

New York: Palgrave/McMillan, 2005, 283 pp.

\section{Vincent Rollet}

\section{OpenEdition}

\section{Journals}

Édition électronique

URL : http://journals.openedition.org/chinaperspectives/1052

DOI : 10.4000/chinaperspectives. 1052

ISSN : 1996-4617

Éditeur

Centre d'étude français sur la Chine contemporaine

Édition imprimée

Date de publication : 1 octobre 2006

ISSN : 2070-3449

\section{Référence électronique}

Vincent Rollet, «Susan Hunter: AIDS in Asia. A Continent in Peril. », China Perspectives [En ligne], 67 september-october 2006, mis en ligne le 01 juin 2007, consulté le 24 septembre 2020. URL : http:// journals.openedition.org/chinaperspectives/1052 ; DOI : https://doi.org/10.4000/chinaperspectives. 1052

Ce document a été généré automatiquement le 24 septembre 2020

(c) All rights reserved 


\section{Susan Hunter: AIDS in Asia. A Continent in Peril.}

New York: Palgrave/McMillan, 2005, 283 pp.

Vincent Rollet

NOTE DE L'ÉDITEUR

Translated from the French original by Michael Black

1 At a moment when the centre of gravity of the HIV/AIDS pandemic that is affecting over 40 million people worldwide is gradually shifting towards Asia, where the virus has already infected over eight million adults and children, Susan Hunter's book sheds essential historical, political, economic and social light on the situation. Hunter, an independent consultant to certain agencies of the United Nations (WHO, UNAIDS, UNICEF), has already published Black Death: AIDS in Africa ${ }^{1}$, considered to be one of the best books to have been written about HIV/AIDS. This time her analysis deals with Asia, and the title itself reveals the conclusion: faced with HIV/AIDS, Asia is a continent in peril.

2 To support this argument, Hunter reviews the figures for AIDS in the first chapter, with a certain ability to make them vivid for the reader. She reminds us in particular that every day 8,200 people die of AIDS and that 15,000 people are infected with HIV (p. 7). There follow a number of statistical projections which aim to give the reader an overview of the global consequences of inaction in the face of this pandemic on the most densely-populated continent in the world. Drawing on a range of research, Hunter speaks of several hundred million cases in Asia by 2025, including 400 million in China, India and Russia (p. 10). This being the case, she considers the question of HIV/AIDS as a threat to international security (p. 8), in the wake of the "security entrepreneurs" who have since 2001 made the connection between international security and HIV/ AIDS in order to give the epidemic a higher priority on the international political agenda. 
3 In the next part of the book, the history of HIV/AIDS is described as a "history of power," which brings into conflict those who hold it and those who do not. According to Hunter this conflict can be encountered firstly through the principal dynamics of the spread of the virus in Asia, in particular what she calls the "infection pumps": the dilapidated state of blood collection systems, the movements of millions of migrant workers, the boom in the sex and drug industries, and the epidemiological risks connected with prison systems (Chapter 2). There follows a history of power, which brings into conflict the countries of "the centre" (the Western countries) and those of "the periphery" (the developing countries), to use the rhetoric of a Marxist-inspired trend in International Relations known as the "Dependence School," to which Hunter seems very attached. Indeed, in exploring the underlying reasons for HIV/AIDS in Asia, and poverty in particular, Hunter argues in favour of the idea that European colonisation in Asia had the devastating effect of the monopolisation of the region's wealth by the colonial powers, and a delay of at least two hundred years in both the democratic process and the modernisation of the region (Chapter 3). To this legacy, with its numerous contemporary consequences, are added more recent factors: the scandals involving infected blood, the smuggling of drugs and people, the rapid development of the sex industry, the increase in floating populations, the low rates of access to health care systems among the most vulnerable, the limited engagement of governments, and the corruption of the elites, which explain the enormous difficulties countries such as China (the last part of Chapter 3), India, Bangladesh, Cambodia and Burma (Chapter 4) have in controlling the present HIV/AIDS pandemic.

4 Since the use of intravenous drugs, or more precisely the sharing of infected needles, is currently one of the principal means of HIV transmission in Asia (accounting for between $30 \%$ and $90 \%$ of cases according to UNAIDS), Hunter provides a detailed summary of the role of the international drug industry in the development of Asian societies since the seventeenth century (Chapter 7). She first reminds us that while the production and sale of opium were at the heart of European competition in Asia, its world-wide sale in the form of heroin is, according to Alfred McCoy, a specialist in international drug trafficking, "the high point of four centuries of Western intervention in the region" (p. 142). Having emphasised the role played by Europeans in this wretched trade, special mention is made of that played by the CIA. The interventions of the Agency in the Golden Triangle and then in Central Asia, in the midst of the ideological conflict of the Cold War, undeniably contributed to strengthening the infrastructure of narcotics production in Asia, and made it possible for these two regions to become the main suppliers of heroin on the world market. This drug production reinforced the isolation of certain Asian countries from the legal economic resources of the international community, transformed some societies into major sources of international instability, and prepared the ground for the HIV/AIDS pandemic we are experiencing today.

5 But the history of power which characterises the growth of HIV/AIDS can also be found at an individual level, particularly in gender relations. Hunter emphasises the extent to which men still continue to dominate or control women not only politically and in terms of access to information, economic resources, food and leisure, but also where their sexual freedom, their mobility, their intimacy, their spirituality and their beliefs about their own nature are concerned (Chapter 6). This chapter also contains a particularly enlightening analysis of the relationship between gender, religion and 
exposure to HIV/AIDS (p. 197 and following). Moreover, Hunter reminds us that the power imbalance is also generational, increasing the vulnerability of both children to HIV/AIDS, as well as of orphans of the epidemic (Chapter 7). These inequalities are materialising in Asia today in the form of a trend similar to that experienced in Africa after 1998, which is to say a rapid narrowing in the male/female ratio of infection by the virus, to the detriment of women ${ }^{2}$, and an inexorable growth in the number of children and young adults being infected.

6 Lastly, because Hunter demonstrates throughout her book that the epidemic is finally shaping a new chapter in the world struggle for equity between genders, classes and generations, she concludes with the relationship between the AIDS epidemic and violations of human rights all over the world. To this end she deals at length with governments which repress "high risk groups" and people who are HIV-positive, as well as with absurd policies which preach abstention in the face of HIV/AIDS-which she calls a "quiet jihad" (p. 263)-, and with the obstacles put in the way of access to generic medicines by the Western pharmaceutical giants.

In the course of the chapters of this political and social history of HIV/AIDS in Asia, the reader can obtain a general idea of the situation in China. Hunter briefly shows how the epidemic of HIV/AIDS emerged in China and how serious it is now, since, depending on the sources of information, the figures range between 650,000 and two million people infected, despite an overall rate of prevalence which remains low. However, the analysis Hunter provides of China's response to this situation could have been more balanced and detailed. It is undeniable that, as she repeatedly reminds us, the Chinese central and local authorities were initially, and for too long, lacking in transparency about the real state of the spread of HIV/AIDS in their country, and subsequently denied the existence of inhuman practices of paid blood collection, which were the source of widespread infection in the centre of the country, and which in particular made orphans of over 200,000 children in the province of Henan. However, leaving it at that, as Hunter tends to do, does not make it possible to provide a balanced and dynamic picture of the evolution in the Chinese response to HIV/AIDS. It seems in fact that since the scandal of contaminated blood in Henan in 2001, and the pressures-both internal and external-brought to bear in favour of greater transparency and a Chinese commitment to an effective fight against the epidemic, a number of steps have been taken by the Chinese authorities. A national strategy based on two five-year plans has emerged, financial commitment to the struggle against HIV/AIDS has been substantially increased, the government has implemented its policy of "4 free services and 1 treatment ${ }^{3 "}$, a number of laws have been promulgated, in particular against discrimination and the paid collection of blood, and a growing number of provinces have agreed to set up a variety of pilot projects supported by bilateral co-operation programmes, international organisations and international NGOs. Moreover, while one cannot speak of "civil society" in China or of freedom of expression about a subject which remains highly sensitive, Hunter could have provided more information and emphasised more strongly the commitment of local associations and of individuals (sociologists, doctors, lawyers, HIV-positive people) who are doing remarkable work to influence the authorities, to support and treat those infected, to promote prevention and to protect the rights of those who are seropositive. Not to speak of this gives a picture of Chinese society as amorphous and awaits solutions from official sources alone. 
8 In the end, one realises that China's principal difficulty in the face of this epidemic today stems from a genuine inability to put into practice at a local level the decisions taken at central level, much more so than, as seems to be Hunter's contention (p. 11 and p. 95), the Chinese government's refusal to act. Several factors can serve as basic explanations for this situation. First of all, with 500 million Chinese living on US\$2 a day, the level of poverty undermines access to treatment and health care, even when they are made available on a national level. Next comes the persistent lack of commitment and openness of certain provinces-Henan in particular-which still do not consider HIV/AIDS to be a priority, and prefer to concentrate on supporting economic growth in order to satisfy the central authorities. In this case, it is all very well for laws and programmes relating to HIV/AIDS to exist at a national level, but if the provincial and local authorities do not consider it urgent to obey them or to set them up in an effective manner, the victims of HIV/AIDS do not benefit from them. The dilapidation and underfinancing of the health system, which drive the hospitals to seek profits, are also sizeable obstacles to their commitment to the struggle against HIV/ AIDS, which they perceive as being anything but lucrative. Lastly, the lack of trained staff and the constant difficulties encountered by the associations in a certain number of provinces in seeking to promote the treatment, support and legal protection of seropositive people deprive the central initiatives of human resources which are essential to the effectiveness of the struggle against the epidemic. However, if Susan Hunter may have given a quick and fairly general overview of the extent of the Chinese response-both state and private-to HIV/AIDS, this is likely to stem from the fact that it is impossible to cover completely so vast a subject in such an enormous region; this cannot therefore be held against her.

9 This being the case, it seems unfortunate that Taiwan is only too rarely mentioned. This is particularly so because the island is experiencing a $20 \%$ annual growth rate in cases of HIV. In 1997 it was the first Asian country to provide anti-retroviral drugs free of charge to seropositive patients, and a large number of local NGOs are engaged in the struggle against HIV/AIDS there.

One last criticism concerns the use in this book of a certain number of scientifically questionable statistics. In the first chapter, Susan Hunter chooses to use the statistical projections of the political analyst N. Eberstadt, which have often been challenged for their excessive pessimism and for being originally from a specialist with little experience in the modelling of infectious diseases. Moreover numerous statistics lack bibliographical references or come only from reports written by actors engaged in advocacy. Thus Susan Hunter states that in China "well documented sources indicate that the number of infections is closer to 20 million" (p. 10), without providing any more detail of the sources in question. This unfortunately deprives the book of a certain scientific credibility.

11 However, it seems that Susan Hunter did not seek to write an academic treatise as such, but rather a strongly committed book, arguing for urgent action in Asia and seeking to touch the reader deeply, in particular by personalising the epidemic through the individual stories which appear as introductions to each chapter. All in all, this is a dense and direct book, which will be indispensable to all those interested in meeting contemporary global challenges, among which the "silent epidemic" of HIV/AIDS is an unavoidable priority. 


\section{NOTES DE FIN}

1. Susan Hunter, Black Death : AIDS in Africa, Palgrave/McMillan, New York, 2003.

2. The case of China is characteristic of the trend in this regard since in 1995 the ratio of women to men was 1:9, while in 2001 it had been reduced to 1:3.4.

3. Free anti-retroviral drugs, free prevention of mother to child infection, free voluntary tests and counselling, free schooling for the orphans of AIDS and free treatment for people living with HIV/AIDS at 127 locations in the country. 